\title{
Rainwater Utilization and Construction of Sponge city
}

\author{
Yiwen Yang \\ Nankai University, Tianjin, China
}

\begin{abstract}
Rainwater utilization is a technical means of comprehensive utilization of rainwater. These include environmentally and economically friendly methods of irrigating farmland and storing water for flushing. The construction of "sponge city" is also the key point that the society pays close attention to nowadays. Rainwater utilization and "sponge city" are to solve the problem of urban waterlogging from the concept to the purpose of construction. Based on certain data, this paper analyzes and expounds the current situation of rainwater utilization at home and abroad, the progress of "sponge city" construction and the desirable experience of advanced countries, summarizes its development trend through case analysis, and puts forward the prospect of future rainwater utilization and "sponge city" construction and development.
\end{abstract}

\section{Introduction}

Through comprehensive consideration and combine the characteristics of the rainwater, economic benefit, environment friendly requirements, to achieve the rain back to used in industry, agriculture, make water back to collectivization in urban ecological residential area, reduce the urban rain flood, storm runoff pollution control, improve the urban ecological environment such as the purpose, set up systems for replenishing groudwater with rainwater, roof garden systems, ecological community rainwater utilization systems, rainwater infiltration system, community buildings for water reuse systems, and under the premise of relevant laws and regulations, use rainwater for the lavatory, irrigation of farmland and road cleanliness such as miscellaneous water. As one of the important links, the construction of "sponge city" plays a positive role in promoting the circulation of rainwater utilization through the constant renewal and improvement of the construction concept, which is conducive to improving the utilization rate of water resources and better realizing the development of urban rainwater utilization.

\section{Current situation of rainwater utilization at home and abroad}

\subsection{Current situation of domestic rainwater utilization}

For rainwater utilization in our country has a long history and valuable experience, but in the $1980 \mathrm{~s}$, our country in the true sense of the research and application of city rainwater utilization is the formal start point, rainwater utilization and the sustainable development of water resources research in China gradually attention by the society, and through the country and the government's efforts, gradually developed in the ninety s. Rainwater utilization is to enable rainwater to be fully absorbed by soil and replenish groundwater during rainfall. Rainwater can be comprehensively utilized in a series of ways to improve water environment and promote water circulation (Figure 1).

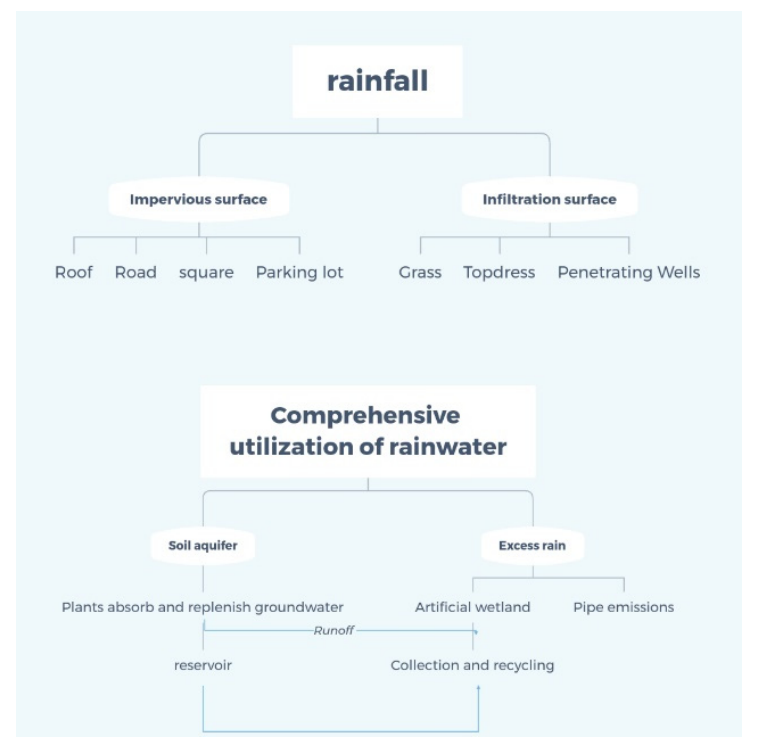

Figure 1. Diagram of comprehensive utilization of rainwater

After stepping into the 21st century, China's urban rainwater utilization process has been significantly accelerated, and the level of rainwater collection and utilization has been gradually improved. Beijing, Shanghai, Xi 'an and other cities have successively implemented a number of rainwater collection and utilization projects. During the 2008 Beijing Olympic Games, in addition to the rainwater collection and utilization system in the central area of the Olympic Park, permeable bricks were widely used in the Olympic venues, sidewalks, squares, courtyards and other places, which

\footnotetext{
*Corresponding author: 903807801@qq.com
} 
reduced surface runoff and pollution and supplemented underground water source ${ }^{1}$.

More than two thousand years ago, $\mathrm{Xi}$ 'an had a reputation of "eight water around chang 'an", in 2022, the peak will appear in front of us again, $\mathrm{Xi}$ 'an government actively supporting the construction of rainwater collection using demonstration projects in recent years, and many new rainwater utilization project, to the construction of "sponge city" took the step of representative significance.

Shanghai has used siphon rainwater system to collect and utilize rainwater in the Exhibition Hall of The National Convention and Exhibition Center and Shanghai Tower successively. In the core area of Shanghai Expo Park, rainwater recovery and utilization system is adopted, including roof greening, shallow underground rainwater storage and infiltration, low-potential green space, infiltration of asphalt pavement and square, etc ${ }^{23}$.

In the aspect of rainwater utilization, China is also faced with many problems. With the rapid development of urbanization in China today, the demand for water quantity and quality also increases due to the increasing penetration rate of urban water (Figure 2). Ubiquitous paving of cement roads, a large number of non permeable paving materials used in the life, caused the urban waterlogging phenomenon is increasingly aggravating, ruined the city water circulation system, the new concept of "sponge city" and practice is put forward, which can effectively reduce the urban waterlogging disasters, to solve the problem of water resources, water environment, such as multiple goals. Therefore, the construction of "sponge city" is very necessary, and has become a practical problem that China pays close attention to nowadays ${ }^{4}$

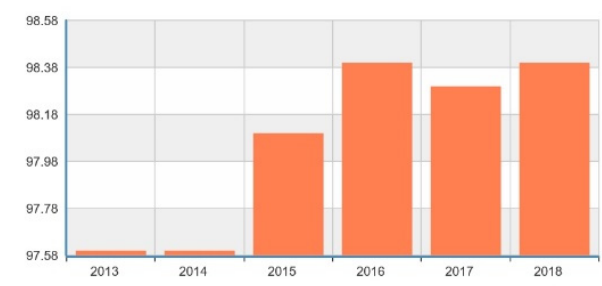

Figure 2. Urban water Penetration rate (\%)

\subsection{Current situation of foreign rainwater utilization}

Due to the shortage of water resources in Japan, the government not only encourages the improvement of water utilization rate and the use of circulating water, but also attaches great importance to the utilization of rainwater. It has been exploring and acquiring new water resources. As a supplementary water source, rainwater has attracted great attention due to its excellent water quality, convenient access and low cost. Pervious asphalt pavements have become common in Tokyo, and rainwater collection facilities, mostly by precipitation and filtration methods, have been installed on some buildings in Japan (Table 1), which are highly efficient. Some rainwater collection facilities are also equipped with chlorine injection devices to regularly disinfect rainwater storage tanks ${ }^{5}$.

Table 1. Rainwater storage facilities and rainwater infiltration method in Japan

\begin{tabular}{|l|l|l|}
\hline \multicolumn{2}{|l|}{ Stormwater storage facilities } & $\begin{array}{l}\text { Rainwater } \\
\text { infiltration method }\end{array}$ \\
\hline Off-site storage & Adjustable pool & $\begin{array}{l}\text { Surface } \\
\text { penetration }\end{array}$ \\
\hline \multirow{3}{*}{ Ground storage } & $\begin{array}{l}\text { Regional storage } \\
\text { facility }\end{array}$ & $\begin{array}{l}\text { Point and line } \\
\text { penetration }\end{array}$ \\
\cline { 2 - 3 } & $\begin{array}{l}\text { Single storage } \\
\text { facilities }\end{array}$ & $\begin{array}{l}\text { Deep well } \\
\text { penetration }\end{array}$ \\
\hline
\end{tabular}

Germany is a world leader in rainwater utilization technology. The main technologies of rainwater utilization in German cities at the present stage are roof rainwater utilization, roof garden rainwater utilization system, rainwater interception and infiltration system and ecological community rainwater utilization system ${ }^{6}$. The law stipulates that stormwater use systems must be considered for design in reconstructed or newly built areas, and the government has formulated a complete set of regulations to guide and restrict the management and use of rainwater. Most of the facilities in Germany have a sound standard and management system to control. The use of rainwater in Potsdamer Platz in Berlin and the International Exhibition Center in Munich are good examples in the world?

\section{Current situation of sponge city construction}

China such as "permeability, water storage and drainage" policy as the construction concept, from macro - river basin scale overall planning, medium - sponge pilot city and micro - city "sponge" construction three aspects for its construction by scientific planning, the national government formulated the general laws and regulations, develop detailed planning, municipal government has special supervision mechanism. It is different from foreign construction methods in many aspects, but it has reached a certain consensus in terms of goals and achievements, which is of great guiding value to the construction of sponge cities in China ${ }^{8}$.

Compared with the developed countries in Europe and The United States, the construction of "sponge cities" in China started relatively late. After the implementation of the construction, China has built pilot "sponge cities" in many cities, including third-tier and fourth-tier cities, with relatively insignificant effects. In 2015, the Ministry of Water Resources issued relevant guidance on the construction of "sponge cities" from the perspective of urban water conservancy, and put forward that the overall goal and sub-indexes of "sponge city" construction should be scientifically and rationally formulated according to local conditions. We will manage urban rivers and lakes, connect them to the river and lake water systems, and do a good job in improving and restoring water ecology. The construction of "sponge city" in foreign countries started earlier and has rich experience. Japan, Australia and other 
countries are representatives of advanced construction and have the leading drainage system and management measures in the world 9 .

By comparison and analysis of Japan, Germany, the United States and Australia, domestic "sponge city" construction has the following experiences in terms of concept design and planning: first, the premise is to introduce management measures by the government, supported by low-impact development technology, guaranteed by green infrastructure and driven by public participation; 2. Formulate increasingly sound laws and regulations, clarify the responsibilities of management agencies at all levels and attach importance to urban infrastructure construction; 3 . Take the lead in establishing drainage projects, pay attention to the construction of rainwater collection and storage system and actively publicize the construction achievements;4.Targeted construction by stages, clear legislative and policy frameworks and effective regulatory systems ${ }^{10}$.

\section{Conclusion}

Rainwater to use advance has made significant achievements, as a good way of promoting water circulation and alleviate the water crisis, will be along with the development of science and technology and technology of advanced widely popularization, The construction of "sponge city" also plays a key role in solving the problem of urban waterlogging due to its constant updating and improvement. Compared with countries with advanced rainwater utilization technology, China started relatively late. However, with the joint efforts of the national government and people, China's rainwater collection and utilization and the construction of "sponge cities" will be significantly improved, gradually approaching the precedent of the world, promoting the water cycle, protecting water resources, creating a water environment, and building a better earth home for our human beings.

\section{References}

1. S Zhao, Z Deng. (2014) Analysis of rainfall usage in Beijing Olympic Park. J. (02):21-24.

2. L Chen, Y Xu, L Zhu, W Zhang, Y Zhang, S Ban, J Gao. (2016) Design of safe ecological rainwater System in The Park of National Convention and Exhibition centre (Shanghai). J. 52(08):101-106.

3. M Yang, C Yin, P Lu, J Wang, X Yin, D Yao, Z Yu. (2015) Application of siphon rainwater system in Shanghai Tower. J. 51(06):76-81.

4. K Liu. (2019) Utilization of rainwater resources and construction of "sponge city". J. (27):66.

5. Y Chen. (2016) Analysis and reference of rainwater integrated management in big cities of Japan. J. 32(10):42-47.
6. J Li, W Che. (2002) Investigation and analysis of urban rainwater utilization technology in Germany. J. (01):47-49.

7. L Zhu, Y Liu, Z Hu, H Yang. (2018) Study on technology Utilization of Rainwater Garden in Shenyang under German urban stormwater management model. J. 45(18):58-60.

8. J Xu, Q Jia, X Wang. (2020) Experience of sponge city construction and comparison at home and abroad. J. 1-10.

9. X Xin, H Wu, Z Su. (2020) Research status and development Trend of "sponge city" construction.

10. J Xu, Q Jia, X Wang. (2020) Experience of sponge city construction and comparison at home and abroad. J. 1-10. 